\title{
Meneladani Nabi Muhammad dan Pengaruhnya terhadap Servant-Leadership dan Perilaku Khidmat
}

\section{Imitating the Prophet of Muhammad and Its Effect on Servant- Leadership and Khidmat Behavior}

\author{
Badruzzaman M. Yunus1, Bambang Qomaruzzaman² \\ 1,2UIN Sunan Gunung Djati Bandung \\ 1,2Jalan AH. Nasution No. 105 Cibiru, Kota Bandung, Jawa Barat, Indonesia \\ Email: badruzzamanmyunus@uinsgd.ac.id ${ }^{1}$, bambang.q.anees@uinsgd.ac.id²
}

\begin{abstract}
Abstrak: Proses pembelajaran materi Agama Islam di Indonesia mendapatkan peringatan dari hasil riset PPIM yang menunjukkan adanya pengaruh pelajaran Pendidikan Agama Islam dalam menumbuhkan sikap intoleransi. Ini berarti proses pembelajaran materi ajaran Islam didorong untuk melakukan perubahan metode atau bahkan materinya agar sikap intoleransi tidak lagi menjadi hasil dari pembelajarannya. Paper ini bertujuan mengajukan model pembelajaran materi ajaran Islam, melalui pembelajaran Tauhid, yang dapat mendorong munculnya sikap Servant-Leadership dan perilaku khidmat (prosocial behavior). Sikap Servant-Leadership(dalam arti pemimpin yang melayani) dan khidmat (perilaku prososial dalam melayani orang lain) dianggap dapat menjadi jembatan bagi munculnya sikap toleransi. Penelitian dilakukan dengan metode Research and Development (R\&D) terhadap 208 Mahasiswa semester pertama Fakultas Ushuludin UIN Sunan Gunung Djati Bandung tahun ajaran 2017-2018. Untuk mengukur peneladanan digunakan Skala yang dimodiifkasi dari CPI (Celebrity Personal Identification) dari Brown Bocarnea, kuesioner Servant Leadership diadaptasikan dari Liden, dan kuesioner khidmat menggunakan pengukuran dari Nickell, G. "The Helping Attitudes Scale". Hasil penelitian menunjukkan bahwa peneladanan terhadap Nabi Muhammad saw berpengaruh pada sikap servantleadership, namun tidak berpengaruh pada sikap khidmat (prososial behavior). Implementasi dari riset ini dapat menjadi pijakan bagi penemuan motode pengajaran materi ajaran Islam.
\end{abstract}

Kata Kunci: pembelajaran Tauhid, teologi, peneladanan, khidmat, servant-leader, manajemen.

\begin{abstract}
The learning process of Islamic material in Indonesia received a warning from the results of PPIM research that showed the influence of Islamic Religious Education lessons in fostering intolerance. This means that the learning process of Islamic teaching materials is encouraged to change the method or even the material so that the attitude of intolerance is no longer the result of learning. This paper aims to propose a model of learning Islamic teaching material, through monotheism learning, which can encourage the emergence of Servant-Leadership attitudes and solemn behavior (prosocial behavior). Servant-Leadership attitude (in the sense of a leader who serves) and solemn (prosocial behavior in serving
\end{abstract}


others) is considered to be a bridge for the emergence of tolerance. The study was conducted by the Research and Development (R\&D) method of 208 first semester students of the Ushuludin Faculty of UIN Sunan Gunung Djati Bandung in the 2017-2018 school year. To measure the model, a modified MMI (Celebrity Personal Identification) CPI (Brown Bocarnea) model was used, the Servant Leadership questionnaire was adapted from Liden, and the solemn questionnaire used measurements from Nickell, G. "The Helping Attitudes Scale." The results showed that the example of the Prophet Muhammad (PBUH) affected servantleadership attitudes, but did not affect the solemn attitude (prosocial behavior). The implementation of this research can be the basis for the discovery of methods of teaching Islamic teaching materials.

Keywords: Monotheism learning, theology, modeling, solemnity, servant-leader, management

\section{Pendahuluan}

Proses pembelajaran materi Agama Islam mengalami anomali saat riset PPIM menunjukkan adanya kontribusi PAI pada munculnya sikap intoleransi ${ }^{1}$. Intoleransi ini terjadi pada level opini dan aksi. Pada Level opini, PPIM menemukan sejumlah siswa/mahasiswa cenderung memiliki pandangan pada opini radikal (58.5\%), opini intoleransi internal (51.1\%) dan opini intoleransi eksternal (34.3\%). Sedangkan dari sisi aksi, siswa/mahasiswa memiliki perilaku keagamaan yang cenderung moderat/toleran. Karena aksi radikal yang dilakukan hanya 7.0\% dan aksi intoleransi eksternal 17.3\%. Namun pada aksi intoleransi internal, siswa/mahasiswa cenderung lebih tinggi, yaitu $34.1 \%{ }^{2}$. Intoleransi merupakan salah satu gejala anti-sosial yang secara psikologis akibat dari kurang terlibat dalam perilaku prososial ${ }^{3}$. Dengan kata lain, ada kecenderungan pembelajaran materi agama Islam tidak mendorong tumbuhnya perilaku prososial.

Perilaku prososial adalah perilaku yang bersifat sukarela dan disengaja untuk menyediakan kesejahteraan orang atau kelompok lain. Tindakan ini dilakukan dengan empati dan oleh rasa prihatin tentang kesejahteraan dan hak orang lain. Perilaku prososial terdiri dari enam aspek, seperti membantu, berbagi, murah hati, menyumbang, kooperatif, dan jujur. Perilaku prososial dibentuk oleh lingkungan ${ }^{4}$, oleh model yang menampilkan perilaku toleran. Dalam konteks Pendidikan Agama Islam (PAI) -yang menjadi objek survey PPIM-- kelangkaan model itu dapat ditemukan dari materi ajar yang sebagian besar berisi perintah dan larangan, sementara sosok tokoh sebagai model kurang dimunculkan. Materi ajar Sejarah Peradaban Islam, biasanya berisi kisah tokoh sejarah, memang diajarkan namun lebih menekankan pada 
pengenalan kronologis peristiwa-peristiwa besar, seperti kronologi imperiumimperium Islam (Umayyah, Abbasiyah, Fatimiyah, Usmaniyah, dan seterusnya). Sementara materi aqidah-akhlak disajikan dalam sejumlah uraian definisi dan keharusan-keharusan berlaku baik, bukan pada peneladanan terhadap model tokoh.

Keberadaan model secara psikologis mempengaruhi perilaku. Teori Kognisi Sosial Bandura menekankan bahwa kepribadian seseorang dibentuk dari model yang diterima individu di lingkungannya ${ }^{5}$. Sikap intoleran dapat diduga berasal dari kelangkaan model perilaku penyebar cinta kasih untuk semesta sebagai misi utama diutusnya Nabi Muhammad. PAI diduga lebih banyak mengeksplorasi aspek kognitif dari ajaran Islam atau menampilkan ajaran Islam sebagai sebuah doktrin yang absolute. Padahal Agama Islam bukan doktrin melainkan cara hidup (din), seruan untuk mengungkapkan kasih sayang dengan amal perbuatan ${ }^{6}$ yang berpusat pada keteladanan terhadap Nabi Muhammad yang hilm -santun dan penuh pengampunan ${ }^{7}$. Tanpa kehadiran sosok Nabi Muhammad ajaran Islam hanya bersisa sejumlah aturan yang miskin kontekstualisasi dan menjadi garang dalam bersikap.

Tariq Ramadan ${ }^{8}$ menegaskan bahwa perilaku intoleransi berasal dari kegagalan memaknai jihad dan ruang sosial. Jihad hanya dimaknai sebagai perang melawan orang kafir, padahal jihad adalah "memobilisasi seluruh kekuatan kemanusiaan dan mengarahkan semua upaya serta memberikan harta benda untuk mengatasi semua kesulitan apakah itu ketidakadilan, kemiskinan, buta huruf, kenakalan atau lainnya" 9 . Ruang sosial oleh umat Islam hanya dimaknai dalam dua pilihan biner, antara ruang damai (dar al-islam) atau ruang berperang (dar al-harb). Dalam logika biner ini, ummat Islam hanya memiliki satu pilihan saat berhadapan dengan ruang publik yang dianggapnya tidak Islami, yakni berperang. Padahal Nabi Muhammad memberikan alternatif ruang ketiga, yakni ruang persaksian (dar al-syahadah), seperti saat memasuki kota Mekkah yang ditundukkan tanpa peperangan melainkan hanya menunjukkan prestasi ummat di hadapan orang-orang tidak beriman ${ }^{10}$. Kisah seperti ini tidak dimunculkan dalam mata pelajaran PAI di Indonesia sehingga wajar jika cara pandang siswa Muslim Indonesia terhadap ruang publik menjadi keliru aksi.

Sebagai model, Nabi Muhammad adalah sosok servant-Leader ${ }^{11}$ yang mengutamakan aspek melayani umat manusia dan memimpinnya menjadi perilaku penyebar rahmat untuk seluruh dunia. Seorang servant-leader adalah orang yang menekankan integritas pribadi dan berfokus pada pembentukan hubungan jangka 
panjang yang kuat ${ }^{12}$ Posisi Nabi Muhammad sebagai servant-leader inilah, bagi Gonaim, yang menjadi kunci sukses penyebaran agama Islam. Kaum Muslim, bagi Ramadhan, harus belajar dari dari kehidupan Nabi yang "mengembangkan ikatan yang kuat dengan non-Muslim atas nama kekerabatan atau persahabatan, atas dasar saling menghormati dan saling percaya, bahkan dalam situasi perang"13. Kaum Muslim perlu untuk meniru perilaku kesabaran Nabi ketika ia berada di minoritas-sebagai agama diperangi di Mekah-atau ketika ia menjadi komunitas mayoritas yang memimpin dengan santun penuh keadilan di Madinah, dan terus demikian atau "tetap sama meskipun berada dalam kesulitan, pengkhianatan, dan perang: tidak ada yang dipaksa untuk berislam, perbedaan dihormati, dan semua orang diperlakukan sama."14.

Keseluruhan uraian dari Ramadan menguatkan apa yang digagas Gonaim bahwa Nabi Muhammad merupakan model Servant-Leader. Servant-leader adalah teori tentang sosok pemimpin yang mau melayani semua orang demi kesejahteraan bersma 15 . Kemunculan Servant-Leader pada satu komunitas membawa pengaruh besar pada perubahan perilaku individu dan kenyamanan hidup bersama ${ }^{16}$. Dalam dunia pendidikan perilaku servant leader dianggap penting untuk meningkatkan hasil yang lebih baik ${ }^{17}$.

Dengan demikian, sikap intoleransi siswa/mahasiswa Indonesia diduga dapat berubah bila mereka mendapatkan model yang dapat mengembangkan perilaku prososial. Model perilaku sosial dalam ajaran Islam, adalah Nabi Muhammad. Penyajian PAI dapat mendorong peserta didik memunculkan Servant Leaderdalam dirinya sebagaimana yang dimodelkan oleh Nabi Muhammad. Artikel ini mengajukan satu eksperimen menampilkan Nabi Muhammad sebagai model Servant-Leader pada mata kuliah Tauhid bagi mahasiswa semester pertama di UIN Sunan Gunung Djati Bandung. Mata kuliah Tauhid tentu saja tidak sama persis dengan PAI, namun inti dari seluruh materi ajaran Islam adalah Tauhid. Tauhid adalah ushuluddin (dasar agama yang menjadi sumber ajaran lain dalam Islam), bila materi Tauhid berorientasi pada sikap prosocial, materi lain akan memiliki orientasi prososial juga.. Seluruh uraian materi Tauhid, pada eksperimen ini, dikaitkan dengan apa yang dilakukan oleh Nabi Muhammad, satu strategi yang menjadikan pembelajaran PAI tidak lagi dipenuhi perintah dan larangan namun mewujud dalam perilaku teladan Nabi Muhammad sebagai seorang pemimpin yang melayani. 
Tujuan penelitian utama paper ini adalah: 1) Untuk menguji bagaimana pengaruh model pembelajaran tauhid berbasis peneladanan terhadap Nabi Muhammad pada tingkat peneladanan, perilaku kepemimpinan yang melayani (Servant Leadership), dan khidmat (perilaku prososial), dan 2) Untuk menentukan apakah ada relasi antara peneladanan terhadap perilaku kepemimpinan yang melayani (Servant Leadership) dan khidmat. Informasi yang dihasilkan dari penelitian ini dapat memberikan para pendidik model pembelajaran materi ajaran Islam yang menghasilkan pribadi toleran.

\section{Kajian Literatur}

\section{Servant Leaders dan Perilaku Khidmat}

Teori Servant Leadership tentang tipe kepemimpinan yang melayani kepentingan bersama daripada memerintah. Teori yang dikembangkan oleh GreenLeaf ini kemudian menginspirasi wacana dan praktek manajemen serta pendidikan. Teori ini misalnya telah mendorong dunia pendidikan agar guru dapat menjadi servant-leader juga atau servant-teacher ${ }^{18}$. Di samping itu kualitas karakter servant-leader juga menjadi tujuan dari outcome pendidikan, yakni peserta didik yang menjadi kepribadian servant leader dalam kesehariannya.

Sebelum teori servant-leader mengemuka, ada banyak riset yang mengaitkan aktivitas guru dengan kepemimpinan di kelas ${ }^{19}$. Kepemimpinan guru di kelas ini ternyata mempengaruhi hasil akhir belajar, motivasi, dan kepuasan siswa ${ }^{20}$. Mengajar dalam karangka servant-leader adalah memimpin dengan cara tertentu sehingga mendorong siswa mendapatkan hasil yang lebih baik ${ }^{21}$. Riset-riset tersebut menunjukkan bahwa kepemimpinan guru yang transformasional di kelas yang memengaruhi siswa secara positif ${ }^{22}$. Riset tentang guru sebagai servant-leader telah banyak dan menunjukkan hasil yang juga positif, seperti membuat guru memiliki tingkat komitmen dan kinerja yang tinggi ${ }^{23}$, mengajar dengan penuh kejelasan, perhatian, penegasan, dan pembelajaran afektif. Keseluruhan riset itu menunjukkan bahwa guru servant leader mempengaruhi kualitas pembelajaran kognitif siswa secara positif 24 .

Riset ini tidak pernah dilakukan sebelumnya, alih-alih mengukur tingkat servantleader pada guru, riset ini justru mengukur mahasiswanya. Alasan mendasarnya adalah jika kualitas servant-leader dapat memberikan pengaruh pada satu organisasi menjadi lebih produktif, maka kualitas yang sama harus dimiliki mahasiswa sehingga kelak 
dapat melakukan perubahan di tengah masyarakat. Di samping itu, sebagai pembanding paper ini akan mengukur tingkat khidmat. Istilah khidmat berarti "melayani", atau melayani kepentingan orang lain demi kebahagiaan orang lain. Kata Khidmat lazim dikenali di dunia spiritualitas dalam Islam dan kerap dikaitkan dengan I'tsar, namun sayangnya tidak berkembang dalam dunia akademik psikologi atau pendidikan Islam. Teori psikologi yang sama dengan khidmat adalah prosocial behavior, yakni perilaku yang bersifat sukarela dan disengaja yang memiliki konsekuensi positif bagi kesejahteraan orang atau kelompok lain ${ }^{25}$. Tindakan ini dilakukan dengan empati dan oleh rasa prihatin tentang kesejahteraan dan hak orang lain. Perilaku prososial terdiri dari enam aspek, seperti membantu, berbagi, kemurahan hati, menyumbang, kooperatif, dan kejujuran.

Perilaku prososial dapat menentukan interaksi dan pembentukan hubungan antar individu, bahkan bisa membuat masyarakat berkembang 26 dapat meningkatkan harga diri, membantu adaptasi psikososial, dan mendapat pengalaman yang membuat perasaan positif seperti bersyukur ${ }^{27}$. Perilaku prososial juga bisa mencegah konflik sosial $^{28}$ sekaligus mengurangi potensi depresi dan kecemasan ${ }^{29}$.

Brodsky dkk. ${ }^{30}$ melaporkan bahwa perilaku prososial akan membuat individu merasa memiliki masyarakatnya, kemudian individu yang memiliki rasa memiliki masyarakatnya akan bersedia secara sukarla untuk aktif bekerja sama dan lebih dermawan). Rasa masyarakat adalah perasaan yang dimiliki oleh anggota masyarakat untuk saling menjaga satu sama lain dalam kelompok, dan saling percaya bahwa setiap anggota membutuhkan akan dipenuhi melalui komitmen bersama ${ }^{31}$. Kemudian penelitian lain menunjukkan bahwa individu dengan perasaan social yang kuat akan memiliki perasaan kesepian yang rendah dan perilaku kejahatan cenderung menurut Chipuer $^{32}$, mendapatkan keuntungan dalam kinerja ${ }^{33}$, meningkatkan jejaring sosial, serta meningkatkan kemampuan mengelola masalah di masyarakat atau organisasi ${ }^{34}$. Sementara tidak adanya rasa memiliki komunitas bisa membuat individu di masyarakat merasa terisolasi, terasing, dan merasa sendirian ${ }^{35}$.

Perilaku khidmat (atau prososial behavior) pada penelitian ini dianggap sebagai antitesa dari intoleran. Jika seseorang memiliki prososial behavior tinggi, diduga akan memunculkan pemikiran dan aksi penuh toleransi. Temuan PPIM tentang tingginya intoleransi pada siswa/mahasiswa Indonesia secara tidak langsung menunjukkan 
tingkat khidmat (prososial behavior) yang rendah. Dengan kata lain, pada siswa yang memiliki khidmat yang tinggi akan memiliki toleransi yang tinggi pula.

\section{Peneladanan}

Peneladanan merupakan inti dari pembelajaran dalam teori belajar social, seperti dikemukakan Bandura ${ }^{36}$ yang meyakini bahwa jika bukan karena pembelajaran observasional, "belajar akan sangat melelahkan, bahkan berbahaya, terutama ketika orang hanya mengandalkan efek dari tindakan mereka sendiri untuk memberi tahu apa yang harus dilakukan. Untungnya, sebagian besar perilaku manusia dipelajari secara observasi melalui pemodelan; dari mengamati orang lain, seseorang membentuk gagasan tentang bagaimana perilaku baru terbentuk dan pada kesempatan berikutnya, informasi ini berfungsi sebagai panduan untuk tindakan"'37.

Teori pembelajaran sosial Bandura ini berkontribusi besar terhadap bidang pendidikan misalnya menekankan pada pentingnya penataan lingkungan belajar yang mendidik. Teori kognitif sosial Bandura menyediakan kerangka kerja untuk memahami penggunaan pemodelan dalam memperbaiki perilaku seseorang. Menurut teori kognitif sosial, kompetensi perilaku, kompetensi sosial dan keterampilan kognitif diperoleh melalui pembelajaran observasional dengan alurindividu mengamati peristiwa dari model, membentuk konstruksi kognitif dari model tersebut, kemudian membentuk perilaku yang sama di masa depan ${ }^{38}$. Penelitian ini menawarkan dukungan bahwa pemodelan dapat berguna untuk mendorong munculnya karakter servant leader pada mahasiswa.

Teori Bandura ini didasarkan padariset "Bobo Doll" yang menunjukkan bagaimana anak-anak belajar dan meniru perilaku yang mereka amatidari orang lain di sekitarnya. Anak-anak, pada eksperimen tersebut mengamati sebuah video mengenai kekerasan perilaku pada Boneka Bobo, ternyata anak-anak itu kemudian meniru tindakan agresif terhadap bonekanya ${ }^{39}$. Dari sini Bandura meyakini observasi seseorang akan ditiru dan membentuk perilaku yang sama.

Teori pemodelan ini sayangnya tidak berkembang di dunia pendidikan agama, khususnya pemodelan terhadap tokoh suci seperti pada Nabi, Ulama, dan sejenisnya. Teori Bandura ${ }^{40}$ sendiri sebenarnya memberikan peluang bagi pemodelan terhadap tokoh secara tidak langsung, yakni pada tokoh yang terdapat pada buku bacaan. Atas dasar teori "pemodelan tidak langsung" inilah Nabi Muhammad disajikan sebagai model 
bagi mahasiswa melalui kisah yang dirancang secara khusus dengan karakter servantleadership.

\section{Servant Leaders dalam Pribadi Nabi Muhammad}

Teori Servant-Leader dikenal karena keefektifannya ${ }^{41}$, dan memiliki potensi untuk membangun pemberdayaan etis dan moral organisasi ${ }^{42}$. Topik servant leader ini kemudian mendorong munculnya pemikiran yang mengaitkanya dengan tokoh suci agama, seperti dengan Mahatma Ghandi ${ }^{43}$, Nabi Muhammad ${ }^{44}$, Yesus ${ }^{45}$, dan lainnya. Faiza Gonaim ${ }^{46}$ menegaskan bahwa Nabi Muhammad telah menunjukkan prinsip servant-leader, keseluruhan riwayat hidupnya merupakan model dari servant-leader jauh sebelum teori ini dirumuskan.

Servant Leader pada mulanya tidak memiliki daftar karakteristik yang spesifik ${ }^{47}$. Baru kemudian Spears ${ }^{48}$ menyusun daftar sepuluh karakteristik kepemimpinan yang efektif dan peduli yaitu dengan ciri-ciri ini adalah: mendengarkan, empati, penyembuhan, kesadaran, persuasi, pandangan ke depan, konseptualisasi, penatalayanan, membangun masyarakat dan komitmen terhadap pertumbuhan komunitas.

Kepemimpinan Nabi Muhammad menunjukkan karakteristik servant-leader ${ }^{49}$. Jika seorang servant-leader memiliki karakteristik peduli dengan membangun hubungan yang efektif dalam satu kehidupan dan dalam organisasi untuk menyeimbangkan kepentingan pribadi dan tujuan bersama ${ }^{50}$ maka Nabi Muhammad menunjukkan karaktersitik itu. Dia memberi, mengorbankan dan melayani untuk memastikan terpenuhinya kebutuhan masyarakat. Dia mendapatkan kepercayaan dan cinta pada orang-orang sebelum menjadi pemimpin atas inisiatif melayani dan kebajikannya ${ }^{51 .}$

Nabi Muhammad adalah seorang yang peduli pada kesejahteraan orang-orang yang dipimpinnya daripada kepentingan egois dirinya sendiri ${ }^{52}$, memiliki sifatbelas kasihan, keadilan kebaikan, berbagi pengaruh ${ }^{53}$. Nabi Muhammad adalah sosok memimpin dengan merujuk pada nilai-nilai utama seperti kebebasan, kesetaraan, keadilan dan kesejahteraan bersama ${ }^{54}$, padahal nilai luar biasa yang dimiliki Nabi adalah kebaikan, kesopanan, kelembutan dan kejujuran ${ }^{55}$. Keseluruhan karakter Nabi Muhammad ini membuatnya menjadi pemimpin unik dalam sejarah umat manusia.

Greenleaf ${ }^{56}$ menegaskan bahwa pemimpin pelayan menaruh minat dan kebutuhan orang lain di atas kepentingan mereka sendiri. Ketika seorang pemimpin menunjukkan kepedulian dan kebaikan kepada orang-orang, ia dapat mempengaruhi pengikutnya 
secara lebih mudah. Inilah salah satu ciri servant-leader yang disebut sebagai "sentuhan produktif"57. Nabi Muhammad dalam sejarah hidupnya juga menggunakan berbagai teknik "sentuhan produktif" seperti berjabat tangan, memeluk persaudaraan, mengusap kepala anak kecil yang yatim.

Greenleaf ${ }^{58}$ menegaskan bahwa kepemimpinan pelayan adalah sebuah pendekatan untuk pemberdayaan, yang berbeda dengan pendekatan hirarkis ${ }^{59}$. Selain itu, pemimpin pelayan berusaha untuk mendorong pengikut mereka untuk tumbuh dan menjadi "lebih sehat, lebih bijak, lebih bebas, lebih otonom, dan lebih cenderung menjadi pelayan"60. Nabi sepanjang hidupnya tidak pernah menggunakan paksaan atau gaya otoriter dalam memperlakukan umatnya. Bahkan dalam peperangan, dia melarang kekerasan seperti membunuh anak-anak, wanita dan orang tua, atau menebang pohon atau membakar rumah. Adair ${ }^{61}$ menegaskan bahwa kepemimpinan Nabi tidak pernah hierarkis atau otoriter.

Keseluruhan kualitas servant-leadership pada diri Nabi Muhammad ini diharapkan dapat menjadi model bagi mahasiswa dalam menjalankan ajaran Islam. Para mahasiswa tidak hanya mengetahui dan memahami perintah dan larangan dalam ajaran Islam, namun juga menjadikan dirinya servant-leader baru di tengah masyarakat Indonesia.

\section{Metode Penelitian}

Penelitian ini menggunakan desain Penelitian dan Pengembangan yang telah disesuaikan dan dimodifikasi dalam tahapnya menjadi empat tahap seperti: (1) studi pendahuluan; (2) pengaturan model konseptual; (3) validasi dan revisi model konseptual dan (4) implementasi model62.

Penelitian ini dilakukan di Universitas Islam Negeri (UIN) Sunan Gunung Djati Bandung Indonesia pada tahun ajaran 2017-2018. Subyek penelitian ini adalah 208 mahasiswa dari tiga program studi (Studi Ilmu Al-Quran \& Tafsir, Ilmu Hadits, dan Aqidah \& Filsafat Islam) semester awal yang mengambil perkuliahan Ilmu Tauhid. Riset dilakukan pada Agustus 2017 sampai dengan Desember 2017. Teknik pengumpulan data meliputi: (1) observasi / observasi partisipatif; (2) studi dokumenter; (3) diskusi kelompok terarah; dan (4) kuesioner. Instrumen yang digunakan adalah: panduan observasi, catatan anekdot, dan panduan Focus Group Discussion untuk pengembangan dan penerapan model pembelajaran kontekstual berbasis kisah Nabi Muhammad. 
Selama pembelajaran eksperimen dilakukan, ada 3 aspek yang akan diukur, yakni peneladanan, Servant Leader, dan Khidmat. Skala Kuesioner peneladanan diambil dari CPI (Celebrity Personal Identificatin) dari Brown dan Bocarnea ${ }^{63}$ yang telah disesuaikan dengan Lingkungan Budaya Indonesia untuk mengukur peneladanan terhadap Nabi. CPI sebenarnya digunakan untuk identiikasi seseorang terhadap selebrity, namun bisa juga digunakan di wilayah agama ${ }^{64}$, seperti terhadap Nabi. Salah satu argument adalah proses identifikasi diri terbuka untuk aspek apapun yang menarik perhatian subyek, karena itu yang diidentifikasi bisa terkait dengan olahraga, dunia kerja, Negara, dan agama65. Selain menggunakan CPI dari Brown dan Bocanea, kuesioner peneladanan ditambahkan dengan pertanyaan terbuka mengenai "judul buku yang dibaca" dan "kisah yang paling inspiratif".

Kuesioner Servant Leadership diadaptasikan dari Liden ${ }^{66}$ yang menetapkan tujuh faktor servant leadership. ketujuh faktor tersebut adalah: ketrampilan konseptual, pemberdayaan, membantu bawahan tumbuh dan berhasil, menempatkan bawahan terlebih dahulu, berperilaku etis, penyembuhan emosional, dan menciptakan nilai bagi masyarakat. Versi asli instrumen ini meminta responden untuk memilih seorang pemimpin dan mengajukan pertanyaan seperti "Dia menekankan pentingnya memberi kembali kepada masyarakat"67. Agar instrumen ini dapat digunakan dalam konteks mahasiswa ada beberapa modifikasi seperti, kata "dia" diganti dengan "saya." Beberapa contoh pertanyaan diantaranya: "saya peduli dengan kesejahteraan orang lain," "saya membutuhkan waktu untuk berbicara dengan yang lain pada tingkat pribadi, "dan" Saya dapat memecahkan masalah akademis dengan gagasan baru atau ide kreatif". Pertanyaan-pertanyaan tersebut diajukan dengan skala Likert 5 poin dengan jawaban mulai dari 1-tidak pernah sampai 5-sangat sering.

Kuesioner khidmat dirumuskan dari teori prososial dan menggunakan pengukuran dari Nickell, G "The Helping Attitudes Scale"68. Melalui skala ini akan diukur kerelaan mahasiswa dalam membantu orang lain, bahkan terhadap orang yang tidak dikenal sama sekali, secara sukarela.

Analisis data kualitatif dilakukan melalui beberapa tahap seperti: (1) melakukan reduksi data dengan meringkas laporan lapangan, mencatat hal-hal pokok yang relevan dengan fokus studi; (2) menyusun secara sistematis berdasarkan kategori dan klasifikasi tertentu; (3) membuat tampilan data berupa tabel atau gambar sehingga korelasi antara satu data ke data lain menjadi jelas dan terpadu; (4) melakukan analisis 
cross site dengan membandingkan dan menganalisis data secara mendalam; (5) menyajikan temuan, membuat kesimpulan dalam bentuk kecenderungan umum dan implikasi aplikasi dan rekomendasi untuk pengembangannya ${ }^{69}$. Analisis kuantitatif dilakukan untuk data yang dikumpulkan dari kuesioner dengan menggunakan analisis statistik korelasi dan regresi dan statistik deskriptif dengan program SPSS versi 17.

Ke-208 responden adalah mahasiswa yang mengambil mata kuliah Tauhid, 106 menjadi kelompok eksperimen dan 106 lainnya kelas kontrol. Keduanya mendapatkan materi yang sama berdasarkan silabus, yakni materi tentang prinsip monoteisme, sifat dan perbuatan Tuhan, posisi Nabi Muhammad dalam system monoteisme, dan seterusnya. Perbedaan kedua kelas ini terletak pada sumber pendukung, sementara kelompok eksperimen ditugaskan khusus membaca buku biografi Nabi Muhammad, yang dirancang secara khusus, kelompok kontrol dibebaskan untuk membaca buku biografi Nabi Muhammad dari sumber umum.

Kemudian kedua kelompok ini mendapat tugas untuk melakukan khidmat (kerja bakti di luar kampus dalam bentuk melayani kepentingan bersama). Kedua kelompok masing-masing dibagi dalam kelompok kecil (4-5) orang untuk memilih Kerja kelompok khidmat sosial yang dilakukan selama 2 minggu. Pengalaman kerja kelompok untuk berkhidmat inilah yang menjadi dasar pengukuran Servant Leadership.

\section{Hasil}

Penelitian ini melibatkan 104 orang Mahasiswa Kelompok Eksperimen dan 104 orang Mahasiswa Kelompok Kontrol di lingkungan UIN SGD Bandung. Kelompok Ekperimen diberi perlakuan yaitu membaca dua buah buku karangan penulis, yakni "Mencari Benih Muhammad" dan "Cukup Muhammad Bagiku”. Dua buku ini dipilih didasarkan pada 2 alasan, yakni buku ini (1) ditulis dengan bahasa yang mudah dipahami usia mahasiswa semester awal; dan (2) menyajikan kisah Nabi Muhammad sebagai sosok manusia yang berproses merespon konteks kehidupannya. Sedangkan kelompok kontrol diberi kebebasan membaca buku apapun ataupun tidak membaca buku.

\section{Tingkat Peneladanan}

Peneladanan terjadi pada saat seseorang melakukan identifikasi diri terhadap subyek yang diteladani. Pada riset ini, kelompok control dan eksperimen Setelah dilakukan pengumpulan dan pengolahan data peneledanan, diperoleh hasil seperti pada table 1: 
Tabel 1

Hasil Analisis Deskriptif Data Peneladanan

\begin{tabular}{llcc}
\hline & Kelompok & Statistic & Std. Error \\
\hline Eksperimen & Mean & 81,58 & 1,012 \\
& Std. Deviation & 5,32 & \\
& Minimum & 57 & \\
\hline Kontrol & Maximum & 100 & \\
& Mean & 70,87 &, 386 \\
& Std. Deviation & 3,93 & \\
& Minimum & 59 & \\
& Maximum & 75 & \\
\hline
\end{tabular}

Dari tabel 1 terlihat bahwa rata-rata skor peneladanan mahasiswa kelompok eksperimen adalah sebesar 81,58 dengan standar deviasi 5,32. Untuk kelompok kontrol skor rata-rata sebesar 70,87 dengan standar deviasi 3,93. Skor tertinggi kelompok eksperimen sebesar 100 dan terendah 57, sedangkan untuk kelompo kontrol skor servant leadership tertinggi yang diperoleh sebesar 75 dan terendah 59.

Untuk melihat perbedaan rata-rata skor Peneladanan masing-masing dilakukan uji t, dengan Hipotesis yang diajukan:

$\mathrm{H}_{0} \quad$ : Tidak Terdapat Perbedaan Tingkat Peneladanan Mahasiswa Antara Kelompok Eksperimen dan Kelompok Kontrol

$\mathrm{H}_{1}$ : Terdapat Perbedaan Tingkat Peneladanan Mahasiswa Antara Kelompok Eksperimen dan Kelompok Kontrol

Setelah dilakukan pengujian diperoleh hasil seperti pada table 2 :

Tabel 2 Hasil

Uji Banding (uji t) data

servant leadership antara kelompok Eksperimen dengan kelompok Kontrol

\begin{tabular}{|c|c|c|}
\hline \multirow{2}{*}{ Kelompok } & \multicolumn{2}{|c|}{ Peneladanan } \\
\hline & rata-rata & SD \\
\hline Eks & 81,58 & 10.324 \\
\hline Kontrol & 70,87 & 3.934 \\
\hline$t_{\text {hitung }}$ & \multicolumn{2}{|c|}{9,888} \\
\hline$t_{\text {tabel }}$ & \multicolumn{2}{|c|}{1,652} \\
\hline & \multicolumn{2}{|c|}{$t_{\text {hitung }}>t_{\text {tabel }}$} \\
\hline Kesimpulan & \multicolumn{2}{|c|}{ Berbeda Signifikan } \\
\hline
\end{tabular}

Ketentuan penarikan kesimpulan:

Jika nilai probabilitas (sig) > 0,05 maka Ho Diterima

Jika nilai probabilitas (sig) < 0,05 maka Ho Ditolak

Atau

Jika $t_{\text {hitung }}>t_{\text {tabel }}$ maka Ho Ditolak 
Jika $t_{\text {hitung }}<\mathrm{t}_{\text {tabel }}$ maka Ho diterima

Dari tabel 2 terlihat bahwa t hitung untuk kedua kelompok adalah 9,888(asumsi varians sama) dengan nilai signifikansi (probabilitas) 0,000. Karena probabilitas <0,05 maka Ho ditolak dan $\mathrm{H} 1$ diterima. Oleh karena itu dapat disimpulkan bahwa terdapat perbedaan tingkat peneladanan antara mahasiswa kelompok ekperimendan kelompok kontrol. Mahasiswa Kelompok eksperimen memiliki rata-rata skor peneladanan sebesar 81,58. Sedangkan rata-rata skor peneladananmahasiswa kelompok sebesar 70,87. Dengan demikian tingkat peneladanan mahasiswa kelompok eksperimen lebih tinggi daripada kelompok kontrol.

\section{Tingkat Servant Leaders}

Setelah dilakukan pengumpulan dan pengolahan data, diperoleh hasil seperti tabel 3:

Tabel 3

Hasil Analisis Deskriptif Data Servant Leadership

\begin{tabular}{llcc}
\hline & Kelompok & Statistic & Std. Error \\
\hline Eksperimen & Mean & 103,64 & 1,148 \\
& Std. Deviation & 11,71 & \\
& Minimum & 70 & \\
& Maximum & 140 & \\
\hline Kontrol & Mean & 97,28 &, 845 \\
& Std. Deviation & 8,62 & \\
& Minimum & 61 & \\
& Maximum & 113 & \\
\hline
\end{tabular}

Dari tabel 3 terlihat bahwa rata-rata skor servant leadership mahasiswa kelompok eksperimen adalah sebesar 103,64 dengan standar deviasi 11,71. Untuk kelompok kontrol skor rata-rata sebesar 97,28 dengan standar deviasi 8,62. Skor tertinggi kelompok eksperimen sebesar 140 dan terendah 70, sedangkan untuk kelompo kontrol skor servant leadership tertinggi yang diperoleh sebesar 113 dan terendah 61.

Untuk membandingkan tingkat servant leadership mahasiswa antara kelompok eksperimen dan kelompok kontrol dilakukan uji t untuk kedua sampel, dengan hipotesis yang diajukan:

Ho : Tidak Terdapat Perbedaan Tingkat Servant Leadership Mahasiswa Antara Kelompok Eksperimen dan Kelompok Kontrol 
H1 : Terdapat Perbedaan Tingkat Servant Leadership Mahasiswa AntaraKelompok Eksperimen dan Kelompok Kontrol

Setelah dilakukan pengujian diperoleh hasil seperti tabe; 4 :

Tabel 4

Hasil Uji Banding (uji t) data servant leadershipantara kelompok Eksperimen dengan kelompok Kontrol

\begin{tabular}{lcc}
\hline \multirow{2}{*}{ Kelompok } & \multicolumn{2}{c}{ Servant Leadership } \\
\cline { 2 - 3 } & rata-rata & SD \\
\hline Eks & 103,64 & 11,711 \\
Kontrol & 97,28 & 8,62 \\
$t_{\text {hitung }}$ & \multicolumn{2}{c}{4,464} \\
$t_{\text {tabel }}$ & \multicolumn{2}{c}{1,652} \\
& \multicolumn{2}{c}{$t_{\text {hitung }}>t_{\text {tabel }}$} \\
\hline Kesimpulan & \multicolumn{2}{c}{ Berbeda Signifikan } \\
\hline
\end{tabular}

Ketentuan penarikan kesimpulan:

Jika nilai probabilitas (sig) > 0,05 maka Ho Diterima

Jika nilai probabilitas (sig) $<0,05$ maka Ho Ditolak

Atau

Jika $t_{\text {hitung }}>t_{\text {tabel }}$ maka Ho Ditolak

Jika $t_{\text {hitung }}<\mathrm{t}_{\text {tabel }}$ maka Ho diterima

Dari tabel 4 terlihat bahwa thitung untuk kedua kelompok adalah4,464(asumsi varians sama) dengan nilai signifikansi (probabilitas) 0,000. Nilai tabel untuk kasus ini adalah sebesar 1,652. Karena nilai $t_{\text {hitung }}>t_{\text {tabel }}$ maka $H_{0}$ ditolak dan $H_{1}$ diterima,sehingga dapat disimpulkan bahwa terdapat perbedaan tingkatServant Leadership antara mahasiswa kelompok ekperimen dan kelompok kontrol. Tabel di atas menunjukkan bahwa mahasiswa Kelompok eksperimen memiliki rata-rata skor Servant Leadershipsebesar 103,64. Sedangkan rata-rata skor Servant Leadership mahasiswa kelompok control sebesar 97,28. Dengan demikian tingkat Servant Leadershipmahasiswa kelompok eksperimen lebih tinggi daripada kelompok kontrol.

\section{Tingkat Perilaku Khidmat}

Setelah dilakukan pengumpulan dan analisis data secara deskriptif tentang data Tingkat Khidmat diperoleh hasil seperti tabel 5 : 
Tabel 5

Hasil Analisis Deskriptif Data Tingkat Khidmat Mahasiswa

\begin{tabular}{llrr}
\hline & Kelompok & \multicolumn{1}{c}{ Statistic } & \multicolumn{2}{c}{ Std. Error } \\
\hline Eksperimen & Mean & 75.37 & 1.389 \\
& Std. Deviation & 4.167 & \\
& Minimum & 60 & \\
\hline Kontrol & Maximum & 98 & .513 \\
& Mean & 73.62 & \\
& Std. Deviation & 5.231 & \\
& Minimum & 62 & \\
& Maximum & 81 & \\
\hline
\end{tabular}

Dari tabel 5 terlihat bahwa rata-rata skor tingkat Khidmat mahasiswa kelompok eksperimen adalah sebesar 75,37 dengan standar deviasi 4,167. Untuk kelompok kontrol skor rata-rata sebesar 73,62 dengan standar deviasi 5,23. Skor tertinggi kelompok eksperimen sebesar 98 dan terendah 60, sedangkan untuk kelompo kontrol skor tingkat Khidmat tertinggi yang diperoleh sebesar 81 dan terendah 62 .

Untuk membandingkan tingkat Khidmat mahasiswa antara kelompok eksperimen dan kelompok kontrol dilakukan uji t untuk kedua sampel, dengan hipotesis yang diajukan:

$\mathrm{H}_{0} \quad$ : Tidak Terdapat Perbedaan Tingkat Khidmat Mahasiswaantara Kelompok Eksperimen dan Kelompok Kontrol

$\mathrm{H}_{1}$ : Terdapat Perbedaan Tingkat Khidmat Mahasiswa antara Kelompok Eksperimen dan Kelompok Kontrol

Setelah dilakukan pengujian diperoleh hasil seperti table 6 :

Tabel 6

Hasil Uji Banding (uji t)

Tingkat Khidmat antara kelompok Eksperimen dengan kelompok Kontrol

\begin{tabular}{lcc} 
& \multicolumn{2}{c}{ Tingkat Khidmat } \\
\cline { 2 - 3 } & \multicolumn{3}{c}{ rata-rata } & SD \\
\hline Eks & 75,37 & 14,16 \\
Kontrol & 73,62 & 5,23 \\
$t_{\text {hitung }}$ & \multicolumn{3}{c}{1,182} \\
$t_{\text {tabel }}$ & \multicolumn{3}{c}{1,652} \\
\multicolumn{3}{c}{$\mathrm{t}_{\text {hitung }}<\mathrm{t}_{\text {tabel }}$} \\
\hline Kesimpulan & \multicolumn{2}{c}{ Tidak Berbeda } \\
\hline
\end{tabular}


Dari tabel 6 terlihat bahwa t hitung untuk kedua kelompok adalah 1,182 (asumsi varians sama) dengan nilai signifikansi (probabilitas) 0,239. Karena probabilitas $>0,05$ maka Ho diterima dan $\mathrm{H} 1$ ditolak. Oleh karena itu dapat disimpulkan bahwa tidak terdapat perbedaan tingkat Khidmatantara mahasiswa kelompok ekperimen dan kelompok kontrol.

\section{Pengaruh Peneladanan terhadap Servant Leadership dan Khidmat}

Pada kelompok eksperimen, pengukuran diteruskan dengan mencari hubungan antara peneladanan $(\mathrm{X})$ terhadap Servany Leadership $\left(\mathrm{Y}_{1}\right)$ dan Khidmat $\left(\mathrm{Y}_{2}\right)$. Pengukuran pengaruh ini dilakukan untuk memperdalam riset, terutama karena tujuan metode pembelajaran ini adalah untuk menjadikan peneladanan sebagai pusat pembelajaran PAI.

a. Pengaruh Peneladanan (X) terhadap Servant Leadership Mahasiswa ( $\left.\mathrm{Y}_{1}\right)$

Untuk mengetahui pengaruh Peneladanan terhadap Servant Leadership dan Khidmat digunakan analisis regresi dan korelasi terhadap dua variabel tersebut, penghitungan menggunakan aplikasi SPSS vers. 20

Tabel 7

Hasil Pengujian Regresi Sederhana Antara Variabel Peneladanan dengan Servant Leadeship

\begin{tabular}{llccccc}
\hline \multirow{2}{*}{ Model } & & \multicolumn{2}{c}{ Standardized } & & \\
\cline { 3 - 5 } & & Unstandardized Coefficients & \multicolumn{2}{c}{ Coefficients } & & Sig. \\
\cline { 2 - 5 } 1 & (Constant) & 28.684 & Std. Error & Beta & & \\
& Peneladanan & .892 & .6969 & & 3.740 & .000 \\
& & .093 & .688 & 9.565 & .000 \\
\hline
\end{tabular}

a. Dependent Variable: Servant Leadership

Dalam tabel 7 diperolehhasil arah regresi $b$ sebesar 0,892 dan konstanta atau $a$ sebesar 28,684. Maka dapat digambarkan bentuk hubungan antara kedua variabel tersebut oleh persaman regresi $\hat{Y}_{1}=28,684+0,892 X$. Selanjutnya untuk mengetahui derajat keberartian dilihat dari nilai signifikansi yaitu sebesar 0,000. Nilai signifikansi ini kurang dari 0,05 sehingga dapat disimpulkan bahwa dengan demikian regresi $Y_{1}$ atas $\mathrm{X}$ disimpulkan koefisien arah regresi berarti dan linier.

Dengan demikian persamaan regresi tersebut $\hat{Y}_{1}=28,684+0,892 X$ dapat untuk menjelaskan ramalan (forecasting) antara kedua variabel tersebut, artinya setiap peningkatan satu skor peneladanan Mahasiswa (X) akan diikuti oleh kenaikan servant 
leadership Mahasiswa ( $\mathrm{Y}_{1}$ ) sebesar 0,892dan pada konstanta 28,684. Dengan Kata lain skor tingkat Servant Leadership Mahasiswa akan bernilai 28,684 jika skor peneladanannya nol (0)

Selanjutnya dilakukan pengujian korelasi antara variable Peneladanan dengan Servant Leadership $\left(\mathrm{Y}_{1}\right)$, untuk mengetahui besarnya hubungan antara variabel $\mathrm{X}$ denganVariabel $\mathrm{Y}_{1}$. Pengujian dilakukan dengan teknik korelasi product moment. Hasilnya dapat dilihat pada tabel 8:

Tabel 8

Korelasi Product moment antara Peneladanan dengan Servant Leadership

\begin{tabular}{llcc}
\hline \multirow{3}{*}{ Peneladanan } & & Peneladanan & Servant Leadership \\
\cline { 2 - 4 } & Pearson Correlation & 1 & $.688^{* *}$ \\
\cline { 2 - 4 } & Sig. (2-tailed) & & .000 \\
\cline { 2 - 4 } & $\mathrm{N}$ & 104 & 104 \\
\hline
\end{tabular}

Dalam tabel 8 dapat diketahui tingkat keeratan hubungan antara peneladanan(X) dengan Servant Leadership Mahasiswa $\left(\mathrm{Y}_{1}\right)$ ditunjukkan oleh koefisien korelasi $\left(\mathrm{r}_{\mathrm{xy} 1}\right)$ sebesar 0,688. Berdasarkan tabel intrepretasi koefisien korelasi dari Sugiyono (2000:175) tersebut, maka harga koefisien korelasi $\left(\mathrm{r}_{\mathrm{xy} 1}\right)$ sebesar 0,688 berarti tingkat pengaruh (korelasinya) kuat/tinggi. Selanjutnya dilakukan uji signifikansi menggunakan ambang batas signifikansi $(\alpha)$ yaitu 0,05 .

Berdasarkan tabel tersebut dapat diketahui bahwa koefisien korelasi sangat signifikan. Hal ini karena nilai sig 0,000< daripada $\alpha=0,05$. Maka dapat dikatakan bahwa pengaruh Peneladanan (X) terhadap Servant Leadership Mahasiswa UIN SGD Bandung $\left(\mathrm{Y}_{1}\right)$ sangat signifikan. Temuan ini menyimpulkan bahwa terdapat pengaruh yang positif Peneladanan terhadap Servant Leadership mahasiswa di lingkungan UIN SGD Bandung.

Dari hasil perhitungan juga diperoleh koefisien determinasi sebesar $\left(r_{x y 1}\right)^{2}=$ $(0,688)^{2} \times 100 \%=47,3 \%$ yang berarti Peneladananmemberikan pengaruh terhadap Servant Leadership mahasiswa UIN SGD Bandung sebesar 47,3\% .

b. Pengaruh Peneladanan $(\mathrm{X})$ terhadap Khidmat Mahasiswa $\left(\mathrm{Y}_{2}\right)$

Dengan menggunakan cara perhitungan yang sama, melalui aplikasi SPSS vers. 20 ditemukan hasil untuk relasi Peneladanan dan Khidmat seperti pada tabel 9: 
Tabel 9

Hasil Pengujian Regresi Sederhana

Antara Variabel Peneladanan dengan Tingkat Khidmat

Coefficients $^{\mathrm{a}}$

\begin{tabular}{|c|c|c|c|c|c|}
\hline \multirow[b]{2}{*}{ Model } & \multicolumn{2}{|c|}{ Unstandardized Coefficients } & \multirow{2}{*}{$\begin{array}{c}\text { Standardized } \\
\text { Coefficients } \\
\text { Beta }\end{array}$} & \multirow[b]{2}{*}{$\mathbf{t}$} & \multirow[b]{2}{*}{ Sig. } \\
\hline & $\mathrm{B}$ & Std. Error & & & \\
\hline 1 (Constant) & 47.579 & 10.822 & & 4.396 & .000 \\
\hline Peneladanan & .341 & .132 & .248 & 2.588 & .011 \\
\hline
\end{tabular}

Dalam tabel 9 diperolehhasil arah regresi $b$ sebesar 0,341 dan konstanta atau $a$ sebesar 47,579. Maka dapat digambarkan bentuk hubungan antara kedua variabel tersebut oleh persaman regresi $\hat{Y}_{2}=47,579+0,341 X$. Selanjutnya untuk mengetahui derajat keberartian dilihat dari nilai signifikansi yaitu sebesar 0,000. Nilai signifikansi ini kurang dari 0,05 sehingga dapat disimpulkan bahwa dengandemikian regresi $\mathrm{Y}$ atas $\mathrm{X}_{1}$ disimpulkan koefisien arah regresi berarti dan linier.

Dengan demikian persamaan regresi tersebut $\hat{Y}_{2}=47,579+0,341 X$ dapat untuk menjelaskan ramalan (forecasting) antara kedua variabel tersebut, artinya setiap peningkatan satu skor peneladanan Mahasiswa (X) akan diikuti oleh kenaikan Tingkat Khidmat mahasiswa $\left(\mathrm{Y}_{2}\right)$ sebesar 0,341 dan pada konstanta 47,579. Dengan Kata lain skor tingkat Khidmat mahasiswa akan bernilai 47,479 jika skor peneladanannya nol (0)

Selanjutnya dilakukan pengujian korelasi antaravariabel Peneladanan dengan Tingkat Khidmat $\left(\mathrm{Y}_{2}\right)$, untuk mengetahui besarnya hubungan antara variabel $\mathrm{X}$ dengan variabel $\mathrm{Y}_{2}$ pengujian dilakukan dengan teknik korelasi product moment. Hasilnya dapat dilihat pada tabel 10:

Tabel 10

Korelasi Product moment antara Peneladanan dengan Tingkat Khidmat

\begin{tabular}{llcc}
\hline & & Peneladanan & Tingkat Khidmat \\
\hline Peneladanan & Pearson Correlation & 1 & $.248^{*}$ \\
& Sig. (2-tailed) & & .011 \\
& $\mathrm{~N}$ & 104 & 104 \\
\hline
\end{tabular}

Dalam tabel 10 dapat diketahui tingkat keeratan hubungan antara peneladanan (X) dengan Tingkat Khidmat Mahasiswa $\left(\mathrm{Y}_{2}\right)$ ditunjukkan oleh koefisien korelasi $\left(\mathrm{r}_{\mathrm{xy}} \mathrm{)}\right.$ sebesar 0,248. Berdasarkan tabel intrepretasi koefisien korelasi dari Sugiyono ${ }^{70}$ tersebut, maka harga koefisien korelasi $\left(\mathrm{r}_{\mathrm{xy} 2}\right)$ sebesar 0,248 berarti tingkat pengaruh (korelasinya) rendah. Selanjutnya dilakukan uji signifikansi menggunakan ambang batas signifikansi $(\alpha)$ yaitu 0,05 . 
Berdasarkan tabel 10 dapat diketahui bahwa koefisien korelasi sangat signifikan. Hal ini karena nilai sig 0,011< daripada $\alpha=0,05$, maka dapat dikatakan bahwa pengaruh Peneladanan (X) terhadap Khidmat mahasiswa UIN SGD Bandung ( $\mathrm{Y}_{2}$ ) sangat signifikan. Temuan ini menyimpulkan bahwa terdapat penagaruh yang positif Peneladanan terhadap Khidmat mahasiswa di lingkungan UIN SGD Bandung.

Dari hasil perhitungan juga diperoleh koefisien determinasi sebesar $\left(r_{x y 2}\right)^{2}=$ $(0,248)^{2} \times 100 \%=6,2 \%$ yang berarti Peneladanan memberikan pengaruh terhadap tingkat Khidmat mahasiswa UIN SGD Bandung sebesar 6,2\% .

\section{Pembahasan}

Hasil penelitian menunjukkan model pembelajaran materi Agama Islam berbasis peneladanan terhadap Nabi Muhammad memiliki pengaruh terhadap tingkat perilaku Servant Leadership dan khidmat (perilaku prososial). Kemudian terdapat relasi antara peneladanan terhadap perilaku Servant Leadership, namun tidak pada tingkat khidmat. Dari hasil pengukuran ada beberapa hasil yang menarik, yakni (a) hasil skor rata-rata peneladanan pada kedua kelompok terpaut tipis, (b) pada kedua kelompok skor khidmatnya rendah, dan (c) relasi pengaruh peneladanan terhadap Servant Leadrship lebih tinggi daripada terhadap tingkat khidmat. Selanjutnya bagian ini akan mendiskusikan ketiga data tersebut.

Pertama, Nilai rata-rata peneladanan antara kelompok control dan eksperimen tampak tidak jauh beda, namun ada pembeda di antara keduanya yang menunjukkan tingkat kualitas peneladanan. Pada kuesioner selain diajukan item pertanyaan tertutup juga diberikan dua pertanyaan terbuka, yakni: 1) Buku apa yang dibaca, sebutkan judulnya?, 2) sebutkan kisah yang paling menarik?. Kuesioner ini untuk mengukur tingkat keseriusan membaca dan diberlakukan secara sama terhadap kelompok control dan eksperimen.

Secara umum, kedua kelompok menyatakan telah membaca Kisah Hidup Nabi Muhammad (Shirah Nabawiyah). Namun ada perbedaan jawaban saat mengisi judul buku yang telah dibaca seperti yang ditunjukan dalam tabel 11. 
Tabel 11

Sumber Vacaan tentang Nabi Muhammad

\begin{tabular}{lclc}
\hline Kelompok Kontrol & & Kelompok Eksperimen & \\
\hline Sumber Bacaan & $\%$ & Sumber Bacaan & $\%$ \\
\hline dari Internet & 30,7 & Buku yang ditentukan & 88,5 \\
dari pelajaran SMA & 26,9 & Buku lain & 11,5 \\
cerita yang dikisahkan ustadz & 22,1 & & \\
buku Hayat Muhammad Haikal & 10,6 & & \\
buku lainnya & 9,7 & & \\
\hline
\end{tabular}

Sementara jawaban terhadap cerita spesifik yang dibaca kedua kelompok ditemukan data pada tabel 12:

Tabel 12

Kisah Nabi Muhammad yang Menginspirasi

\begin{tabular}{|c|c|c|c|}
\hline \multicolumn{2}{|l|}{ Kelompok Kontrol } & \multicolumn{2}{|l|}{ Kelompok Eksperimen } \\
\hline Tema Kisah & $\%$ & Tema Kisah & $\%$ \\
\hline Nabi Menyuapi Yahudi Buta & $33,6 \%$ & $\begin{array}{l}\text { Masa Kanak-kanak Nabi: } \\
\text { menderita dan berjuang }\end{array}$ & 20,1 \\
\hline $\begin{array}{l}\text { Nabi membalas lemparan dengan } \\
\text { kiriman Roti }\end{array}$ & $28,8 \%$ & $\begin{array}{l}\text { Cara Nabi menghadapi cacian dan } \\
\text { hinaan }\end{array}$ & 19,2 \\
\hline Peperangan & $25,6 \%$ & Peristiwa pewahyuan di gua hira & 17,3 \\
\hline Tidak fokus & $21 \%$ & $\begin{array}{l}\text { Kesabaran dan kesantuan } \\
\text { memperjuangkan Islam }\end{array}$ & 11,5 \\
\hline & & Perdagangan Nabi & 10,6 \\
\hline & & Peristiwa Hijrah & 10,6 \\
\hline & & Saat menata Madinah & 7,7 \\
\hline & & $\begin{array}{l}\text { Perjanjian Hudaibiyah } \\
\text { Lain-lain }\end{array}$ & 2,8 \\
\hline
\end{tabular}

Tabel di 11 dan tabel 12 menunjukkan bahwa mahasiswa Kelompok eksperimen terpusat pada kisah-kisah popular yang berkembang di masyarakat. Satu indikasi yang dapat ditafsirkan bahwa kelompok kontrol sebenarnya tidak membaca buku kisah hidup Nabi Muhammad. Sementara pada kelompok eksperimen jenis kisah yang menginspirasi sedemikian bervariasi dan lebih terfokus pada aspek-aspek tertentu. Perbedaan ini karena kelompok eksperimen memang ditugaskan membaca buku tertentu., sementara kelompok kontrol dibiarkan. Karena kelompok control dibiarkan, ada kecenderungan mereka tidak membaca buku sama sekali, seperti data pada tabel 11, membaca dari internet $(30,7 \%)$ dapat berarti hanya artikel singkat yang menjadi sumber bacaan, dari buku pelajaran $(26,9 \%)$ juga artikel singkat karena buku pelajaran PAI tidak memuat kisah lengkap tentang Nabi Muhammad, kemudian dari ceramah ustadz $(22,1 \%)$ jelas sama sekali tidak membaca.

Kedua, nilai khidmat pada kedua kelompok menunjukkan skor rata-rata yang rendah, yang berarti bahwa metode pembelajaran yang dieksperimenkan tidak Kontekstualita, Vol. 33, No. 2, 2018 
berpengaruh pada munculnya perilaku menolong orang lain tanpa pamrih. Dalam riset ini, perilaku Khidmat berbeda dengan perilaku Servant Leader dari sisi lingkungan pembentuknya. Data Servant Leader diukur berdasarkan pengalaman mahasiswa setelah melakukan kerjasama dalam kelompok. Ini dimaksudkan agar factor kepemimpinan individu dapat terukur, yakni ketika dikaitkan dengan kerjasama menyelesaikan masalah bersama. Jadi, objek Servant Leader jelas, yakni kelompok terbatas, di antara mahasiswa yang sudah saling kenal. Sementara objek khidmat, berbuat baik pada orang lain tanpa syarat, objeknya tidak dikenal, tak terbatas, dan sangat luas.

Ketiga, terhadap data bahwa hasil analisis pengaruh peneladanan terhadap Servant Leader $(47,3 \%)$ cukup besar sementara terhadap Khidmat sangat rendah (6,2\%). Perbedaan nilai ini dapat terjadi karena dua hal, (1) dipengaruhi oleh skor ratarata tingkat khidmat yang rendah, dan (2) model yang ditampilkan pada buku kisah hidup Nabi Muhammad lebih menonjolkan aspek servant-leader. Di luar dari ketiga catatan ini, menghadirkan sosok Nabi Muhammad sebagai model bagi cara beragama yang "memimpin dan melayani" berhasil ditunjukkan.

Penelitian ini memang tidak memfokuskan pada toleransi, namun dengan asumsi intoleran merupakan sikap antisosial dan toleran merupakan sikap prososial maka tumbuhnya sikap servant leader dan khidmat menjadi modal atau jembatan bagi tumbuhnya sikap toleransi. Bila intoleransi berarti menolak (lalu menyalahkan) apa yang dianggap berbeda, maka melalui sikap servant leader relasi terhadap yang berbeda akan disikap secara "lebih sehat, lebih bijak dan lebih cenderung melayani" ${ }^{71}$. Pada sisi lain, khidmat (walaupun pada riset ini hasilnya tidak begitu besar) mendorong tumbuhnya rasa komunitas yang akan memunculkan sikap saling menjaga dan saling percaya melalui komitmen bersama ${ }^{72}$.

\section{Kesimpulan}

Hasil ini dapat ditafsirkan bahwa metode pembalajaran yang dieksperimenkan lebih lebih besar pengaruhnya pada peneladanan dan Servant Leader, namun kecil pengaruhnya pada pemupukan rasa khidmat. Data ini juga dapat ditafsirkan sebagai rendahnya kemauan mahasiswa untuk berkhidmat terhadap kelompok yang lebih luas dan orang yang tidak dikenal. Temuan ini telah cukup menunjukkan sumber dari 
perilaku intoleran pada siswa/mahasiswa Muslim di Indonesia, sekaligus menjadi pekerjaan rumah baru bagi pembelajaran ajaran agama Islam.

\section{Catatan}

${ }^{1}$ PPIM, Executive Summary: Api Dalam Sekam: Keberagamaan Gen Z Survei Nasional Tentang Sikap Keberagamaan Di Sekolah Dan Universitas Di Indonesia (Jakarta: Pusat Pengkajian Islam dan Masyarakat (PPIM) UIN Syarif Hidayatullah Jakarta, 2017).

2 (PPIM, 2017:3)

${ }^{3}$ Xinyin Chen et al., "Sociability and Prosocial Orientation as Predictors of Youth Adjustment: A SevenYear Longitudinal Study in a Chinese Sample," International Journal of Behavioral Development 26, no. 2 (March 2002): 128-36, https://doi.org/10.1080/01650250042000690.

${ }^{4}$ Marylène Gagné, "The Role of Autonomy Support and Autonomy Orientation in Prosocial Behavior Engagement," Motivation and Emotion 27, no. 3 (2003): 199-223, https://doi.org/10.1023/A:1025007614869.

${ }^{5}$ A. Bandura, Social Learning Theory (New York: General Learning Press, 1977).

${ }^{6}$ Karen Armstrong, Compassion 12 Langkah Menuju Hidup Berbelas Kasih (Bandung: Mizan, 2012).

${ }^{7}$ Armstrong, 2012.

8 (Ramadhan, "The Call to Jihad". 2004)

${ }^{9}$ Ramadan, 2004.

${ }^{10}$ Tariq Ramadan, Teologi Dialog Islam-Barat Pergumulan Muslim Eropa (Bandung: Mizan, 2002).

${ }^{11}$ Faiza Gonaim, "An Analysis of the Life of Prophet Muhammad: Servant-Leadership and Influence," International Journal of Humanities and Social Science Invention 5, no. 4 (2016): 53-59.

12 Jill W. Graham, "Servant-Leadership in Organizations: Inspirational and Moral," The Leadership Quarterly 2, no. 2 (June 1991): 105-19, https://doi.org/10.1016/1048-9843(91)90025-W.

13 Tariq Ramadan, In The Footsteps of the Prophet Lessons from the Life Muhammad (Oxford: Oxford University Press, 2007).

14 Ramadan, 2007.

15 R. Greenleaf, Servant Leadership (New Jersey: Paulist Press, 1977).

${ }^{16}$ J. Sipe and D. Frick, Seven Pillars of Servant-Leadership: Practicing the Wisdom Ofleading by Serving (New York: Pavlist Press, 2009).

${ }^{17}$ San Bolkan and Alan K. Goodboy, "Transformational Leadership in the Classroom: The Development and Validation of the Student Intellectual Stimulation Scale," Communication Reports 23, no. 2 (October 2010): 91-105, https://doi.org/10.1080/08934215.2010.511399; San Bolkan, Alan K. Goodboy, and Darrin J. Griffin, "Teacher Leadership and Intellectual Stimulation: Improving Students' Approaches to Studying through Intrinsic Motivation," Communication Research Reports 28, no. 4 (October 2011): 337-46, https://doi.org/10.1080/08824096.2011.615958; A. Noland and K. Richards, "The Relationship among Transformational Teaching and Student Motivation and Learning," The Journal of Effective Teaching 14, no. 3 (2014): 5-20.

${ }^{18}$ Aaron Noland and Keith Richards, "Servant Teaching: An Exploration of Teacher Servant Leadership on Student Outcomes," Journal of the Scholarship of Teaching and Learning 15, no. 6 (2015): 16, https://doi.org/10.14434/josotl.v15i6.13928.

19 Rebecca M. Chory and James C. McCroskey, "The Relationship between Teacher Management Communication Style and Affective Learning," Communication Quarterly 47, no. 1 (January 1999): 111, https://doi.org/10.1080/01463379909370120; V.P. Richmond and J.C. McCroskey, Organizational Communication for Survival (Englewood Cliffs, NJ: Prentice Hall, 1992)..

20 James S. Pounder, "Transformational Classroom Leadership," Educational Management Administration \& Leadership 34, no. 4 (October 2006): 533-45, https://doi.org/10.1177/1741143206068216; Bolkan and Goodboy, "Transformational Leadership in the Classroom: The Development and Validation of the Student Intellectual Stimulation Scale"; Bolkan, Goodboy, and Griffin, "Teacher Leadership and Intellectual Stimulation: Improving Students' Approaches to Studying through Intrinsic Motivation"; Noland and Richards, "The Relationship among Transformational Teaching and Student Motivation and Learning."

${ }^{21}$ Sean M. Horan et al., "Testing Leader-Member Exchange Theory as a Lens to Understand Students' Classroom Justice Perceptions and Antisocial Communication," Communication Quarterly 61, no. 5 (November 2013): 497-518, https://doi.org/10.1080/01463373.2013.799511; Bolkan, Goodboy, 
and Griffin, "Teacher Leadership and Intellectual Stimulation: Improving Students' Approaches to Studying through Intrinsic Motivation."

22 James S. Pounder, "Transformational Classroom Leadership: A Novel Approach to Evaluating Classroom Performance," Assessment \& Evaluation in Higher Education 33, no. 3 (June 2008): 23343, https://doi.org/10.1080/02602930701292621.

23 Dirk van Dierendonck and Inge Nuijten, "The Servant Leadership Survey: Development and Validation of a Multidimensional Measure," Journal of Business and Psychology 26, no. 3 (September 2011): 249-67, https://doi.org/10.1007/s10869-010-9194-1.

24 Bolkan, Goodboy, and Griffin, “Teacher Leadership and Intellectual Stimulation: Improving Students' Approaches to Studying through Intrinsic Motivation."

25 Nancy Eisenberg and Paul Henry Mussen, The Roots of Prosocial Behavior in Children (Cambridge: Cambridge University Press, 1989), https://doi.org/10.1017/CB09780511571121.

26 S. Singh and V. Y. Teoh, "Enhancing Prosocial Behavior among College Students: Exploring the Role of Abstract Mindset," International Journal of Law and Social Sciences 3, no. 1 (2013): 28-32, https://doi.org/10.5176/2251-2853_3.2.154.

27 Gian Vittorio Caprara and Patrizia Steca, "Self-Efficacy Beliefs As Determinants of Prosocial Behavior Conducive to Life Satisfaction Across Ages," Journal of Social and Clinical Psychology 24, no. 2 (March 2005): 191-217, https://doi.org/10.1521/jscp.24.2.191.62271.

${ }^{28}$ K. Kartono, Patologi Sosial 2: Kenakalan Remaja (Jakarta: Rajawali Press, 2005).

${ }^{29}$ N. Krause, "Meaning in Life and Mortality," The Journals of Gerontology Series B: Psychological Sciences and Social Sciences 64B, no. 4 (July 2009): 517-27, https://doi.org/10.1093/geronb/gbp047.

30 A. M. Omoto and M. Snyder, "Influences of Psychological Sense of Community on Voluntary Helping and Prosocial Action," in The Psychology of Prosocial Behavior: Group Processes, Intergroup Relations, and Helping, ed. S. Stumer and M. Snyder (New Jersey: Wiley-Balckwel, 2010).

31 David W. McMillan and David M. Chavis, "Sense of Community: A Definition and Theory," Journal of Community Psychology 14, no. 1 (January 1986): 6-23, https://doi.org/10.1002/15206629(198601)14:1<6::AID-JCOP2290140103>3.0.CO;2-I.

32 Heather M. Chipuer, "Dyadic Attachments and Community Connectedness: Links with Youths' Loneliness Experiences," Journal of Community Psychology 29, no. 4 (2001): 429-46, https://doi.org/10.1002/jcop.1027.

33 L Thomas, "Building Student Engagement And Belonging In Higher Education At A Time Of Change," What Works? Student Retention \& Success, 2012.

${ }^{34}$ Lisa F. Berkman and Thomas Glass, "Social Integration, Social Networks, Social Support, and Health," in Social Epidemiology, ed. L. Berkman and I. Kawachi, vol. 1 (New York: Oxford University Press, 2000).

35 Susan J. Farrell, Tim Aubry, and Daniel Coulombe, "Neighborhoods and Neighbors: Do They Contribute to Personal Well-Being?," Journal of Community Psychology 32, no. 1 (January 2004): 925, https://doi.org/10.1002/jcop.10082.

36 Barkha Devi et al., "Application of Bandura's Social Cognitive Theory in the Technology Enhanced, Blended Learning Environment," International Journal of Applied Research 3, no. 1 (2017): 721-24.

37 Bandura, A. Social Learning Theory. New York: General Learning Press, 1977.

38 TM Scaria, PB Valsaraj, and M. Pias, "The Effectiveness of Video Teaching over Lecture Cum Demonstration in Improving Knowledge and Skill, of Nursing Students on Antenatal Examination," International Journal of Nursing Education 5, no. 1 (2013): 228, https://doi.org/10.5958/j.09749357.5.1.026.

39 Jennifer E. Lansford, “Bobo Doll Experiment," in Encyclopedia of Personality and Individual Differences (Cham: Springer International Publishing, 2016), 1-3, https://doi.org/10.1007/978-3-319-280998_1214-1; Peter Graham and Adeela Arshad-Ayaz, "Learned Unsustainability: Bandura's Bobo Doll Revisited," Journal of Education for Sustainable Development 10, no. 2 (September 2016): 262-73, https://doi.org/10.1177/0973408216650954.

40 Bandura, A. Social Learning Theory. New York: General Learning Press, (1977)

41 Ramona M. Wis, "The Conductor as Servant-Leader," Music Educators Journal 89, no. 2 (November 2002): 17, https://doi.org/10.2307/3399837.

42 Ginny Boyum, "The Historical and Philosophical Influences on Greenleaf's Concept of Servant Leadership: Setting the Stage for Scientific Theory Building," Servant Leadership Research Roundtable, no. August (2006), https://doi.org/ED501687. 
43 Annette Barnabas and Paul Sundararajan Clifford, "Mahatma Gandhi - An Indian Model of Servant Leadership," International Journal of Leadership StudiesJournal of Leadership Studies 7, no. 2 (2012): 132-50.

${ }^{44}$ Rafik I. Beekun, "Character Centered Leadership: Muhammad (p) as an Ethical Role Model for CEOs," Journal of Management Development 31, no. 10 (2012): 1003-20, https://doi.org/10.1108/02621711211281799; Gonaim, "An Analysis of the Life of Prophet Muhammad: Servant-Leadership and Influence."

45 Justin A Irving, "Leadership Reflection: A Model for Effective Servant Leadership Practice: A BiblicallyConsistent and Research-Based Approach to Leadership," Journal of Biblical Perspectives in Leadership 3, no. 2 (2011): 118-28, https://doi.org/10.1227/01.neu.0000407873.87315.7d; Anthony and I. Amadi, "Jesus the Servant Leader: A Model to All Teachers and School Administrators," Education Research Journal 7, no. 9 (2017): 239-44; Gabriel Kofi Boahen Nsiah, "Leading as Jesus Led: Christ Models of Leadership," Open Journal of Leadership 02, no. 04 (2013): 103-5, https://doi.org/10.4236/ojl.2013.24016.

46 Faiza Gonaim, "An Analysis of the Life of Prophet Muhammad: Servant-Leadership and Influence." International Journal of Humanities and Social Science Invention 5, no. 4 (2016): 53-59)

47 Wis, "The Conductor as Servant-Leader."

48 Spears, Larry C. "Character and Servant Leadership: Ten Characteristics of Effective, Caring Leaders." The Journal of Virtues \& Leadership 1, no. 1 (2010): 25-30)

${ }^{49}$ Gonaim, "An Analysis of the Life of Prophet Muhammad: Servant-Leadership and Influence."

50 Spears, "Character and Servant Leadership: Ten Characteristics of Effective, Caring Leaders."

51 Ibn Hisham, Sirat Ibn Hisham: Biography of The Prophet, trans. Inas A. Farid (Nasr City: Al-Falah Foundation, 2000); R Rodgers, "The Generalship of Muhammad, the Prophet of Allah," in The Generalship of Muhammad (Florida: Florida Scholarship Online, 2012), 231-250, https://doi.org/10.5744/florida/9780813037660.003.0009.

52 Marc H Applebaum, “A Phenomenological Psychological Study of Muslim Leaders' Attitudes toward Connection with the Prophet Muhammad" (Saybrook University, 2009).

53 Abbas J. Ali, "Islamic Perspectives on Leadership: A Model," International Journal of Islamic and Middle Eastern Finance and Management 2, no. 2 (2009): 160-80, https://doi.org/10.1108/17538390910965167.

54 J. M. Burns, Leadership (New York: Harper \& Row, 1978).

55 Gonaim, "An Analysis of the Life of Prophet Muhammad: Servant-Leadership and Influence."

56 Greenleaf, R. Servant Leadership. New Jersey: Paulist Press, 1977)

${ }^{57}$ L Pellicer, Caring Enough to Lead: How Reflective Practice Leads to Moralleadership (Thousand Oak, CA: Corwin Press, 2008).

58 Greenleaf, R. Servant Leadership. New Jersey: Paulist Press, 1977)

59 Carolyn Crippen, "The Democratic School: To Serve or to Lead," Canadian Journal of Educational Administration and Policy, no. 47 (2005): 1-17.

60 Greenleaf, Servant Leadership.

61 (2010)

62 W. Brown and Mihai Bocarnea, "Celebrity-Persona Identification Scale," in Handbook of Research on Electronic Surveys and Measurements, ed. Rodney A Reynolds, Robert Woods, and Jason D. Baker, Fifthy (New York: IGI Global, 1989), 302-5, https://doi.org/10.4018/978-1-59140-792-8.ch037.

63 Brown, W., and Mihai Bocarnea. "Celebrity-Persona Identification Scale." In Handbook of Research on Electronic Surveys and Measurements, edited by Rodney A Reynolds, Robert Woods, and Jason D. Baker, Fifthy., 302-5. New York: IGI Global, 1989. https://doi.org/10.4018/978-1-59140-7928.ch037)

64 Fred A. Mael and Blake E. Ashforth, "Identification in Work, War, Sports, and Religion: Contrasting the Benefits and Risks," Journal for the Theory of Social Behaviour 31, no. 2 (June 2001): 197-222, https://doi.org/10.1111/1468-5914.00154.

65 John C. Haughey, “Does Loyalty in the Workplace Have a Future?,” Business Ethics Quarterly 3, no. 1 (January 1993): 1, https://doi.org/10.2307/3857378; G.P Fletser, Loyalty: An Essay on the Morality of Relationships (New York: Oxford University Press, 1993); G.F Shea, Company Loyalty: Earning It, Keeping It (New York: American Management Association, 1987).

66 Robert C. Liden et al., "Servant Leadership: Development of a Multidimensional Measure and MultiLevel Assessment," The Leadership Quarterly 19, no. 2 (April 2008): 161-77, https://doi.org/10.1016/j.leaqua.2008.01.006; Mark T Green et al., "Servant Leadership: A 
Quantitative Review of Instruments and Related Findings," Servant Leadership: Theory and Practice 2, no. 2 (2015): 76-96, https://doi.org/10.1177/1059601106287091.

67 Liden et al., "Servant Leadership: Development of a Multidimensional Measure and Multi-Level Assessment."

68 Gary S Nickell, "The Helping Attitude Scale Gary," Annual Convention of the American Psychological Association, no. 218 (1998): 1-10.

${ }^{69}$ R. Fraenkel Jack and E. Wallen Norman, How to Design and Evaluate Research in Education, 2 nd ed. (New York: McGraw-Hill Inc., 1993).

70 Sugiyono. Statistika Untuk Penelitian. Bandung: CV Alfabeta, 2012)

${ }^{71}$ Greenleaf, Servant Leadership. New Jersey: Paulist Press, 1977.

72 McMillan and Chavis, "Sense of Community: A Definition and Theory."

\section{Daftar Pustaka}

Adair, J. The Leadership of Muhammad. London: Kogan Page Limited, 2010.

Ali, Abbas J. "Islamic Perspectives on Leadership: A Model." International Journal of Islamic and Middle Eastern Finance and Management 2, no. 2 (2009): 160-80. https://doi.org/10.1108/17538390910965167.

Anthony, and I. Amadi. "Jesus the Servant Leader: A Model to All Teachers and School Administrators." Education Research Journal 7, no. 9 (2017): 239-44.

Applebaum, Marc H. "A Phenomenological Psychological Study of Muslim Leaders' Attitudes toward Connection with the Prophet Muhammad." Saybrook University, 2009.

Armstrong, Karen. Compassion 12 Langkah Menuju Hidup Berbelas Kasih. Bandung: Mizan, 2012.

Bandura, A. Social Learning Theory. New York: General Learning Press, 1977.

Barnabas, Annette, and Paul Sundararajan Clifford. "Mahatma Gandhi - An Indian Model of Servant Leadership." International Journal of Leadership StudiesJournal of Leadership Studies 7, no. 2 (2012): 132-50.

Beekun, Rafik I. "Character Centered Leadership: Muhammad (p) as an Ethical Role Model for CEOs." Journal of Management Development 31, no. 10 (2012): 1003-20. https://doi.org/10.1108/02621711211281799.

Bolkan, San, and Alan K. Goodboy. "Transformational Leadership in the Classroom: The Development and Validation of the Student Intellectual Stimulation Scale." Communication Reports 23, no. 2 (October 2010): 91-105. https://doi.org/10.1080/08934215.2010.511399.

Bolkan, San, Alan K. Goodboy, and Darrin J. Griffin. "Teacher Leadership and Intellectual Stimulation: Improving Students' Approaches to Studying through Intrinsic Motivation." Communication Research Reports 28, no. 4 (October 2011): 337-46. https://doi.org/10.1080/08824096.2011.615958.

Boyum, Ginny. "The Historical and Philosophical Influences on Greenleaf's Concept of Servant Leadership: Setting the Stage for Scientific Theory Building." Servant Leadership Research Roundtable, no. August (2006). https://doi.org/ED501687.

Brown, W., and Mihai Bocarnea. "Celebrity-Persona Identification Scale." In Handbook of Research on Electronic Surveys and Measurements, edited by Rodney A Reynolds, Robert Woods, and Jason D. Baker, Fifthy., 302-5. New York: IGI Global, 1989. https://doi.org/10.4018/978-1-59140-792-8.ch037. 
Burns, J. M. Leadership. New York: Harper \& Row, 1978.

Caprara, Gian Vittorio, and Patrizia Steca. "Self-Efficacy Beliefs As Determinants of Prosocial Behavior Conducive to Life Satisfaction Across Ages." Journal of Social and Clinical $\begin{array}{lllll}\text { Psychology 24, no. } 2 \text { (March 2005): } & \text { 191-217. }\end{array}$ https://doi.org/10.1521/jscp.24.2.191.62271.

Chen, Xinyin, Mowei Liu, Kenneth H. Rubin, Guo-zhen Cen, Xiangping Gao, and Dan Li. "Sociability and Prosocial Orientation as Predictors of Youth Adjustment: A Seven-Year Longitudinal Study in a Chinese Sample." International Journal of Behavioral Development 26, no. 2 (March 2002): 128-36. https://doi.org/10.1080/01650250042000690.

Chipuer, Heather M. "Dyadic Attachments and Community Connectedness: Links with Youths' Loneliness Experiences." Journal of Community Psychology 29, no. 4 (2001): 429-46. https://doi.org/10.1002/jcop.1027.

Chory, Rebecca M., and James C. McCroskey. "The Relationship between Teacher Management Communication Style and Affective Learning." Communication Quarterly 47, no. 1 (January 1999): 1-11. https://doi.org/10.1080/01463379909370120.

Crippen, Carolyn. "The Democratic School: To Serve or to Lead." Canadian Journal of Educational Administration and Policy, no. 47 (2005): 1-17.

Cuthill, Michael. "Coolangatta: A Portrait of Community Well-Being." Urban Policy and Research 20, no. 2 (June 2002): 187-203. https://doi.org/10.1080/08111140220144489.

Devi, Barkha, Mridula Das, Mridul Das, and Bidita Khandelwal. "Application of Bandura's Social Cognitive Theory in the Technology Enhanced, Blended Learning Environment." International Journal of Applied Research 3, no. 1 (2017): 721-24.

Dierendonck, Dirk van, and Inge Nuijten. "The Servant Leadership Survey: Development and Validation of a Multidimensional Measure." Journal of Business and Psychology 26, no. 3 (September 2011): 249-67. https://doi.org/10.1007/s10869-010-9194-1.

Eisenberg, Nancy, and Paul Henry Mussen. The Roots of Prosocial Behavior in Children. Cambridge: Cambridge University 1989. https://doi.org/10.1017/CB09780511571121.

F. Berkman, Lisa, and Thomas Glass. "Social Integration, Social Networks, Social Support, and Health." In Social Epidemiology, edited by L. Berkman and I. Kawachi, Vol. 1. New York: Oxford University Press, 2000.

Farrell, Susan J., Tim Aubry, and Daniel Coulombe. "Neighborhoods and Neighbors: Do They Contribute to Personal Well-Being?" Journal of Community Psychology 32, no. 1 (January 2004): 9-25. https://doi.org/10.1002/jcop.10082.

Fletser, G.P. Loyalty: An Essay on the Morality of Relationships. New York: Oxford University Press, 1993.

Fraenkel Jack, R., and E. Wallen Norman. How to Design and Evaluate Research in Education. 2nd ed. New York: McGraw-Hill Inc., 1993.

Gagné, Marylène. "The Role of Autonomy Support and Autonomy Orientation in Prosocial Behavior Engagement." Motivation and Emotion 27, no. 3 (2003): 199-223. https://doi.org/10.1023/A:1025007614869.

Gonaim, Faiza. "An Analysis of the Life of Prophet Muhammad: Servant-Leadership and Influence." International Journal of Humanities and Social Science Invention 5, no. 4 (2016): 
53-59.

Graham, Jill W. "Servant-Leadership in Organizations: Inspirational and Moral." The Leadership Quarterly 2, no. 2 (June 1991): 105-19. https://doi.org/10.1016/1048-9843(91)90025-W.

Graham, Peter, and Adeela Arshad-Ayaz. "Learned Unsustainability: Bandura's Bobo Doll Revisited." Journal of Education for Sustainable Development 10, no. 2 (September 2016): 262-73. https://doi.org/10.1177/0973408216650954.

Green, Mark T, Richard A. Rodriguez, Carol A. Wheeler, and Barbara Baggerly-Hinojosa. "Servant Leadership: A Quantitative Review of Instruments and Related Findings." Servant Leadership: $\quad$ Theory and Practice 2, no. 2 (2015): 76-96. https://doi.org/10.1177/1059601106287091.

Greenleaf, R. Servant Leadership. New Jersey: Paulist Press, 1977.

Haughey, John C. "Does Loyalty in the Workplace Have a Future?” Business Ethics Quarterly 3, no. 1 (January 1993): 1. https://doi.org/10.2307/3857378.

Hisham, Ibn. Sirat Ibn Hisham: Biography of The Prophet. Translated by Inas A. Farid. Nasr City: Al-Falah Foundation, 2000.

Horan, Sean M., Rebecca M. Chory, Shannon T. Carton, Erin Miller, and Peter C. J. Raposo. "Testing Leader-Member Exchange Theory as a Lens to Understand Students' Classroom Justice Perceptions and Antisocial Communication." Communication Quarterly 61, no. 5 (November 2013): 497-518. https://doi.org/10.1080/01463373.2013.799511.

Irving, Justin A. "Leadership Reflection: A Model for Effective Servant Leadership Practice: A Biblically-Consistent and Research-Based Approach to Leadership." Journal of Biblical Perspectives in Leadership 3, no. 2 (2011): 118-28. https://doi.org/10.1227/01.neu.0000407873.87315.7d.

Kartono, K. Patologi Sosial 2: Kenakalan Remaja. Jakarta: Rajawali Press, 2005.

Krause, N. "Meaning in Life and Mortality." The Journals of Gerontology Series B: Psychological Sciences and Social Sciences 64B, no. 4 (July 2009): 517-27. https://doi.org/10.1093/geronb/gbp047.

Krouse, H J, J A Fisher, and H N Yarandi. "Utility of Video Modeling as an Adjunct to Preoperative Education." Southern Online Journal of Nursing Research 2, no. 8 (2001): 1-38.

Lansford, Jennifer E. "Bobo Doll Experiment." In Encyclopedia of Personality and Individual Differences, 1-3. Cham: Springer International Publishing, 2016. https://doi.org/10.1007/978-3-319-28099-8_1214-1.

Liden, Robert C., Sandy J. Wayne, Hao Zhao, and David Henderson. "Servant Leadership: Development of a Multidimensional Measure and Multi-Level Assessment." The Leadership Quarterly 19, no. 2 (April 2008): 161-77. https://doi.org/10.1016/j.leaqua.2008.01.006.

Mael, Fred A., and Blake E. Ashforth. "Identification in Work, War, Sports, and Religion: Contrasting the Benefits and Risks." Journal for the Theory of Social Behaviour 31, no. 2 (June 2001): 197-222. https://doi.org/10.1111/1468-5914.00154.

McGinley, Meredith, and Gustavo Carlo. "Two Sides of the Same Coin? The Relations between Prosocial and Physically Aggressive Behaviors." Journal of Youth and Adolescence 36, no. 3 (March 2007): 337-49. https://doi.org/10.1007/s10964-006-9095-9.

McMillan, David W., and David M. Chavis. "Sense of Community: A Definition and Theory." Journal of Community Psychology 14, no. 1 (January 1986): 6-23. 
https://doi.org/10.1002/1520-6629(198601)14:1<6::AID-JCOP2290140103>3.0.CO;2-I.

Nickell, Gary S. "The Helping Attitude Scale Gary." Annual Convention of the American Psychological Association, no. 218 (1998): 1-10.

Noland, A., and K. Richards. "The Relationship among Transformational Teaching and Student Motivation and Learning." The Journal of Effective Teaching 14, no. 3 (2014): 5-20.

Noland, Aaron, and Keith Richards. "Servant Teaching: An Exploration of Teacher Servant Leadership on Student Outcomes." Journal of the Scholarship of Teaching and Learning 15, no. 6 (2015): 16. https://doi.org/10.14434/josotl.v15i6.13928.

Nsiah, Gabriel Kofi Boahen. "Leading as Jesus Led: Christ Models of Leadership." Open Journal of Leadership 02, no. 04 (2013): 103-5. https://doi.org/10.4236/ojl.2013.24016.

Nursan, Cinar, Köse Dilek, and Altinkaynak Sevin. "Breastfeeding Self-Efficacy of Mothers and the Affecting Factors." Aquichan 14, no. 3 (September 2014): 327-35. https://doi.org/10.5294/aqui.2014.14.3.5.

Omoto, A. M., and M. Snyder. "Influences of Psychological Sense of Community on Voluntary Helping and Prosocial Action." In The Psychology of Prosocial Behavior: Group Processes, Intergroup Relations, and Helping, edited by S. Stumer and M. Snyder. New Jersey: WileyBalckwel, 2010.

Pellicer, L. Caring Enough to Lead: How Reflective Practice Leads to Moralleadership. Thousand Oak, CA: Corwin Press, 2008.

Pounder, James S. "Transformational Classroom Leadership: A Novel Approach to Evaluating Classroom Performance." Assessment \& Evaluation in Higher Education 33, no. 3 (June 2008): 233-43. https://doi.org/10.1080/02602930701292621.

_-_. "Transformational Classroom Leadership." Educational Management Administration \& $\begin{array}{lllll}\text { Leadership } 34, \quad \text { no. } 4 \text { (October } & \text { 2006): }\end{array}$ https://doi.org/10.1177/1741143206068216.

PPIM. Executive Summary: Api Dalam Sekam: Keberagamaan Gen Z Survei Nasional Tentang Sikap Keberagamaan Di Sekolah Dan Universitas Di Indonesia. Jakarta: Pusat Pengkajian Islam dan Masyarakat (PPIM) UIN Syarif Hidayatullah Jakarta, 2017.

Ramadan, Tariq. In The Footsteps of the Prophet Lessons from the Life Muhammad. Oxford: Oxford University Press, 2007.

———. Teologi Dialog Islam-Barat Pergumulan Muslim Eropa. Bandung: Mizan, 2002.

_—_. “The Call to Jihad." Tariq Ramadan Blog, 2004.

Richmond, V.P., and J.C. McCroskey. Organizational Communication for Survival. Englewood Cliffs, NJ: Prentice Hall, 1992.

Rodgers, R. "The Generalship of Muhammad, the Prophet of Allah." In The Generalship of Muhammad, 231-250. Florida: Florida Scholarship Online, 2012. https://doi.org/10.5744/florida/9780813037660.003.0009.

Rogers, Laura Q., Courtney Matevey, Patricia Hopkins-Price, Prabodh Shah, Gary Dunnington, and Kerry S. Courneya. "Exploring Social Cognitive Theory Constructs for Promoting Exercise Among Breast Cancer Patients." Cancer Nursing 27, no. 6 (November 2004): 462???473. https://doi.org/10.1097/00002820-200411000-00006.

Scaria, TM, PB Valsaraj, and M. Pias. "The Effectiveness of Video Teaching over Lecture Cum 
Demonstration in Improving Knowledge and Skill, of Nursing Students on Antenatal Examination." International Journal of Nursing Education 5, no. 1 (2013): 228. https://doi.org/10.5958/j.0974-9357.5.1.026.

Sharma, M, and DE.A Corbin. "Preliminary Study of the Effects of an Innovative Social Cognitive Theory Driven Yoga Based Behavioural Intervention on Smoking Cessation." California Journal of Health Promotion 4, no. 4 (2006): 63-67.

Shea, G.F. Company Loyalty: Earning It, Keeping It. New York: American Management Association, 1987.

Singh, S., and V. Y. Teoh. "Enhancing Prosocial Behavior among College Students: Exploring the Role of Abstract Mindset." International Journal of Law and Social Sciences 3, no. 1 (2013): 28-32. https://doi.org/10.5176/2251-2853_3.2.154.

Sipe, J., and D. Frick. Seven Pillars of Servant-Leadership: Practicing the Wisdom Ofleading by Serving. New York: Pavlist Press, 2009.

Spears, Larry C. "Character and Servant Leadership: Ten Characteristics of Effective, Caring Leaders." The Journal of Virtues \& Leadership 1, no. 1 (2010): 25-30.

Sugiyono. Statistika Untuk Penelitian. Bandung: CV Alfabeta, 2012.

Thomas, L. "Building Student Engagement And Belonging In Higher Education At A Time Of Change." What Works? Student Retention \& Success, 2012.

Wis, Ramona M. "The Conductor as Servant-Leader." Music Educators Journal 89, no. 2 (November 2002): 17. https://doi.org/10.2307/3399837. 